INTERNATIONAL JOURNAL OF MULTIDISCIPLINARY RESEARCH AND ANALYSis

ISSN(print): 2643-9840, ISSN(online): 2643-9875

Volume 04 Issue 04 April 2021

DOI: 10.47191/ijmra/v4-i4-19, Impact Factor: 6.072

Page No.- $484-488$

\title{
Evaluation of the Vietnamese Consumers' Intention to Buy Chinese Garment Products
}

\author{
Pham Thi Thuy Van ${ }^{1}$, Nguyen Thi Anh Tram², Le Thi Hai Ha ${ }^{3}$ \\ 1,2,3 University of Labor and Social Affairs, Vietnam
}

\begin{abstract}
S: Chinese garment products were present throughout the domestic market of Vietnam, both in large cities and in rural areas, attracting the majority of low-income and low-end customers. The main objective of this study was to identify, evaluate, and to measure the attributes of the Vietnamese consumers' intention to buy Chinese garment products. The study was based on a field survey using a semi-structured questionnaire on a sample of 600 consumers in Hanoi city and Ho Chi Minh city. But, only 406 filled questionnaires were satisfactory and therefore included in the analysis. By using seceral statistical analytical tools, i.e. descriptive statistics, Cronbach's Alpha analysis, the study has identified and measured four (4) attributes of the Vietnamese consumers' intention to buy Chinese garment products. Based on the findings, some recommendations are given for the Vietnamese consumers' intention to buy Chinese garment products and domestic textile and garment firms in Vietnam.
\end{abstract}

KEYWORDS: Intention to buy products, Chinese garment products, marketing, consumers

JEL code: M31, M10

\section{INTRODUCTION}

Consumers must make everyday shopping decisions with overloaded information (Arnould et al. 2004). When the market expanded, information was increasing, consumers who lacked experience about products could rely on the image of the country which was the origin to evaluate the product, determine the confidence in the product. After that, they decided to buy or not (Gurhan-Canli \& Maheswaran, 2000).

Over the years, garment products have significantly contributed to the economic and social development in Vietnam. According to the textile industry development plan of the Ministry of Industry and Trade, by 2020 the textile industry would become one of the key industries which were export-oriented and could meet the high demand of consumers, create more jobs for workers and be more attractive to foreign investors in Vietnam.

Marketing and distribution activities were weak stages of the textile industry in Vietnam. The difficulties in exporting were a good opportunity for domestic textile and garment firms in Vietnam to seriously recognize the domestic market. Vietnam ranked among the top 10 textile and garment exporting countries in the world, but had not yet been dominant in the domestic market. So far only about one third of Vietnamese textiles and garments were consumed domestically. Chinese garments products were present throughout the domestic market of Vietnam, both in large cities and in rural areas, attracting the majority of low-income and lowend customers (Thoa, 2012).

In the domestic market of Vietnam, domestic textile and garment firms in Vietnam also faced many competitors, of which Chinese garment products was a leading competitor. In order to be successful in the market, among other conditions, domestic textile and garment firms in Vietnam needed to understand their competitors and knew how customers had an attitude about competitors' products (Thong \& Ha, 2018).

From the above reasons, it is necessary and meaningful to research the Vietnamese consumers' intention to buy Chinese garment products.

\section{THEORETICAL BACKGROUND AND LITERATURE REVIEW}

\section{Theoretical background}

The theory of marginal benefits by Marshall (1890) states that the purchasing decision was the result of rational and economically conscious procurement. However, this viewpoint does not fully explain the fluctuation of sales under the influence of internal and external factors (environment). 


\section{Evaluation of the Vietnamese Consumers' Intention to Buy Chinese Garment Products}

The theory of rational behavior (TRA) was proposed by Fishbein and Ajzen (1975). The theory asserts that people often weighed results before performing different actions and they would choose to take actions that could lead to the results they wanted. Intention is the tool of continuation between attitudes and behavior. Behavior is defined by a person's intention to take an action in a given context. Intention is perceived as the representation of the willingness to take action.

Theory of planning behavioral (TPB) is an extended theory of rational behavior theory (Ajzen \& Fishbein, 1980; Fishbein \& Ajzen, $1975)$, this theory is created due to the limitation of the previous theory with the assumption that human behavior was purely due to moral control.

\section{Literature review}

Consumers' buying intention is one of the most important factors marketers often use in predicting future sales and to identify impactful policies to stimulate consumers' buying behavior. Fishbein and Ajzen (1975) have shown that, if you wanted to know whether an individual performed a certain behavior, it was necessary and simple to know whether that person intended to perform that behavior or not. According to Warshaw (1980), most theoretical models of consumers' behavior (eg, Engel et al., 1978; Howard, 1963) also showed that purchasing intention is a variable interference between consumer attitudes and buying behavior. According to Thong (2003), intention to act denoted the tendency of the individual to act towards the object.

Research on consumers' buying intention, Ajzen and Driver (1992); Pierre et al (2005); Schlosser et al. (2006) argued that intention had a broader meaning than behavior and would often have a positive effect on an individual's actions.

Mathur's study of the consumers' toothpaste branding behavior (1998) shows that consumer choice was related to comparing intentions and any possible choice scenarios involving comparison at many levels. Jin and Kang (2011) used the scale of Mathur (1998), which includes four indicators to measure the buying intention of Chinese consumers for an American-branded fashion product.

The TPB (Ajzen \& Fishbein, 1980) is used to explain consumers' intention to buy domestic products such as safe food (Huong, 2014); intention to shop online (Thang, 2015), etc.

Inheriting the research results of previous studies, we choose the purchasing intention scale from Mathur's (1998) research results, because: (i) China and Vietnam are two countries that belong to Asia, there are similarities in intention to buy goods; (ii) Mathur (1998) referred to the buying intention of Chinese consumers for a foreign product.

\section{METHODOLOGY}

Research Subject: The subject of this research is of the Vietnamese consumers' intention to buy Chinese garment products.

\section{Qualitative Research Methodology}

This research used a qualitative research methodology based on some in-depth interviews with three (3) lecturers with extensive experiences in marketing in textile and garment firms in Vietnam of the National Economics University and University of Labor and Social Affairs. These are the two leading universities in Vietnam in training marketing and business administration. At the same time, three (3) experts were also interviewed who are marketing manager in textile and garment firms. The contents of the interviews focused on the subject of the Vietnamese consumers' intention to buy Chinese garment products' attributes.

Based on findings from a number of previous studies and findings from the interviews with those experts, this research has identified the Vietnamese consumers' intention to buy Chinese garment products (YDMH) in four (4) attributes as presented in Table 1 below.

Table 1. Attributes of the Vietnamese consumers' intention to buy Chinese garment products

\begin{tabular}{|l|l|l|}
\hline Code & Scale & Sources \\
\hline The Vietnamese consumers' intention to buy Chinese garment products (YDMH) \\
\hline YDMH1 & Buying Chinese garment products is the best & Mathur (1998) \\
\hline YDMH2 & I will buy Chinese garments products whenever possible & Mathur (1998) \\
\hline YDMH3 & $\begin{array}{l}\text { There is a possibility that I would buy Chinese garment products if they are } \\
\text { available in the area where I live }\end{array}$ & Mathur (1998) \\
\hline YDMH4 & I would suggest people to buy Chinese garment products & Mathur (1998) \\
\hline
\end{tabular}

\section{Quantitative Research Methodology}

For the purpose of this research, a questionnaire was designed which consisted of four (4) variables with a 5-point Likert scale from 1: "Strongly disagree" to 5: "Strongly agree". The method of data collection was accomplished through the survey with a number of consumers in Hanoi city and Ho Chi Minh city. A total of 600 questionnaires were sent and received the filled 


\section{Evaluation of the Vietnamese Consumers' Intention to Buy Chinese Garment Products}

questionnaires with full information for data entry and analysis from 406 respondents. The size of this sample was consistent with study of Hair et al. (1998) that the research sample must be at least 5 times the total number of indicators in the scales. The questionnaire of this study included four (4) indicators, and therefore, the minimum sample size to be achieved is $5 * 4=20$ observations. Then, data from these 406 questionnaires was cleaned and coded with the necessary information in the questionnaires, inputted the analyzed by using SPSS22.

The steps of data analysis were as follows:

(i) Descriptive statistics,

(ii) Cronbach's Alpha to assess the reliability of the scale

\section{RESEARCH RESULTS}

\subsection{Descriptive Statistics}

Information of data collected is shown in Table 2. It shows that among the 406 respondents, about $23.2 \%$ were male while the remaining 312 (76.8\%) were female. Of these, 245 of them (or $60.3 \%$ ) were from 18 to 25 years old, 92 of them (or $22.7 \%$ ) were from 26 to 35 years old, 68 of them (or 16.7\%) were from 36 to 54 years old, and $0.3 \%$ of the participants were over 55 years old. Among the respondents, $55.7 \%$ of the participants have income less than 5 millions VND, $17.2 \%$ of the participants have income from 5 millions VND to 7.5 millions VND, 13.3\% of the participants have income from 7.6 millions VND to 10.0 millions VND, $6.2 \%$ of the participants have income from 10.1 millions VND to 12.5 millions VND, $2.2 \%$ of the participants have income from 12.6 millions VND to 15.0 millions VND, 0.5\% of the participants have income from 15.1 millions VND to 17.5 millions VND, $0.7 \%$ of the participants have income from 17.6 millions VND to 20.0 millions VND, and over 20 millions VND accounted for $4.2 \%$

Table 2: Respondents by gender, age and income

\begin{tabular}{|c|c|c|c|}
\hline & Frequency & Percent & Cumulative Percent \\
\hline \multicolumn{4}{|l|}{ Gender } \\
\hline Male & 94 & 23.2 & 23.2 \\
\hline Female & 312 & 76.8 & 100.0 \\
\hline \multicolumn{4}{|l|}{ Age } \\
\hline From 18 to 25 years old & 245 & 60,3 & 60,3 \\
\hline From 26 to 35 years old & 92 & 22.7 & 70.6 \\
\hline From 36 to 54 years old & 68 & 16.7 & 99.8 \\
\hline Over 54 years old & 1 & 0.3 & 100.0 \\
\hline \multicolumn{4}{|l|}{ Income } \\
\hline less than 5 millions VND & 226 & 55.7 & 55.7 \\
\hline $\begin{array}{l}\text { From } 5 \text { millions VND to } 7.5 \text { millions } \\
\text { VND }\end{array}$ & 70 & 17.2 & 72.9 \\
\hline $\begin{array}{l}\text { From } 7.6 \text { millions VND to } 10 \text { millions } \\
\text { VND }\end{array}$ & 54 & 13.3 & 86.2 \\
\hline $\begin{array}{l}\text { From } 10.1 \text { millions VND to } 12.5 \\
\text { millions VND }\end{array}$ & 25 & 6.2 & 92.4 \\
\hline $\begin{array}{l}\text { From } 12.6 \text { millions VND to } 15 \text { millions } \\
\text { VND }\end{array}$ & 9 & 2.2 & 94.6 \\
\hline $\begin{array}{l}\text { From } 15.1 \text { millions VND to } 17.5 \\
\text { millions VND }\end{array}$ & 2 & 0.5 & 95.1 \\
\hline $\begin{array}{l}\text { From } 17.6 \text { millions VND to } 20 \text { millions } \\
\text { VND }\end{array}$ & 3 & 0.7 & 95.8 \\
\hline Over 20 millions VND & 17 & 4.2 & 100.0 \\
\hline Total & 406 & 100.0 & \\
\hline
\end{tabular}

Next, Table 3 indicates that the respondents agree with the dependent variables of "The Vietnamese consumers' intention to buy Chinese garment products" where four attributes. With the same statement, most consumers answered at a level of disagreement. The mean values of the variables observed in the Vietnamese consumers' intention to buy Chinese garment products are quite equal and well below the average. Therefore, the Vietnamese consumers' intention to buy Chinese garment 


\section{Evaluation of the Vietnamese Consumers' Intention to Buy Chinese Garment Products}

products in the two big cities, Hanoi and Ho Chi Minh City, is lower than average.

Table 3. Descriptive Analysis of Attributes of the Vietnamese consumers' intention to buy Chinese garment products

\begin{tabular}{|l|l|l|l|l|l|}
\hline & $\mathrm{N}$ & Minimum & Maximum & Mean & Std. Deviation \\
\hline YDMH1 & 406 & 1.0 & 5.0 & 2.239 & .7663 \\
\hline YDMH2 & 406 & 1.0 & 4.0 & 2.128 & .7971 \\
\hline YDMH3 & 406 & 1.0 & 4.0 & 2.039 & .7815 \\
\hline YDMH4 & 406 & 1.0 & 5.0 & 1.897 & .8160 \\
\hline Valid N (listwise) & 406 & & & $\mathbf{2 . 0 7 6}$ & \\
\hline
\end{tabular}

\subsection{Cronbach's Alpha}

The Vietnamese consumers' intention to buy Chinese garment products has been measured by the Cronbach's Alpha. Results of testing Cronbach's alpha of attributes are presented in Table 4 below. The results also show that attributes of the dependent variables have Cronbach's Alpha coefficients that are greater than 0.6 , and the correlation coefficients of all attributes are greater than 0.3. So, all the attributes of the dependent variables are statistically significant (Hair et al, 2010; Hoang \& Chu, 2008).

Table 4. Results of Cronbach's Alpha Testing of Attributes

\begin{tabular}{|c|c|c|c|c|}
\hline Cronbach's Alpha & $\mathrm{N}$ of Items & & & \\
\hline \multirow[t]{2}{*}{.875} & 4 & & & \\
\hline & $\begin{array}{l}\text { Scale Mean if Item } \\
\text { Deleted }\end{array}$ & $\begin{array}{l}\text { Scale Variance if Item } \\
\text { Deleted }\end{array}$ & $\begin{array}{l}\text { Corrected Item- } \\
\text { Total Correlation }\end{array}$ & $\begin{array}{l}\text { Cronbach's Alpha if Item } \\
\text { Deleted }\end{array}$ \\
\hline YDMH1 & 6.064 & 4.682 & .606 & .887 \\
\hline YDMH2 & 6.175 & 3.967 & .843 & .795 \\
\hline YDMH3 & 6.264 & 4.076 & .821 & .805 \\
\hline YDMH4 & 6.406 & 4.331 & .672 & .865 \\
\hline
\end{tabular}

\section{DISCUSSION AND IMPLICATIONS}

Economic integration is an inevitable trend for the Vietnamese economy. Accordingly, China - Vietnam economic relations are also developing rapidly. Trade deficit from China accounted for almost all of Vietnam's trade deficit (Bui, 2014). However, the quality control of imported goods was currently too lax, causing many poor quality products to be massively imported into Vietnam, causing damage to consumers (Mien, 2017).

In the segment of low and medium - priced goods, domestic manufacturers are being dominated by sources of imported goods into the Vietnamese market, mainly by quota, especially Chinese garment products. It is increasingly difficult for domestic firms in this segment to compete with products imported from another home country. Therefore, in the low and medium price segment, garment suppliers in Hanoi city and Ho Chi Minh city need to ensure more product quality, variety of types and designs, more competitive prices than Chinese garment products, and at the same time standardize the retail distribution system so that consumers can easily buy products when they need.

Research results show that the Vietnamese consumers' intention to buy Chinese garment products is below average. It proves that consumers have quite a high intention to buy garment products from domestic textile and garment firms in Vietnam or from firms from other countries around the world such as Japan, European countries, etc. In order to promote purchasing intentions of garment products from domestic textile and garment firms in Vietnam, domestic textile and garment firms in Vietnam need to, such as.

(i) Invest in advanced technology to produce high quality products, improve production efficiency, diversify products to serve the diverse needs of consumers; pay attention to developing unique items in order to have a position in the minds of customers;

(ii) Ensure stability and improve skills for all types of craftsmen, train a team of professional fashion designers, with professional competencies to grasp fashion trends in the country and abroad through appropriate recruitment, training and motivational policies; combine short-term training with long-term training, combine formal training with on-the-job training, combine domestic training with sending staff abroad for training;

(iii) Find solutions to reduce product costs, increase price competitiveness;

(iv) Exploit available distribution channels such as markets, supermarkets; persuade to display products in fashion stores through preferential policies and focus on wholesale channels. 


\section{Evaluation of the Vietnamese Consumers' Intention to Buy Chinese Garment Products}

(v) Enterprises need to apply information technology to the design and product samples such as applying software programs for fashion design to help improve the efficiency of design, contributing to productivity, creating more patterns and minimizing design errors (Nhung et al. 2016).

\section{REFERENCES}

1) Ajzen, I., \& Driver, B. L. (1992). Application of the theory of planned behaviour to leisure choice. Journal of Leisure Research, 24(3), 207-224.

2) Ajzen, I., \& Fishbein, M. (1980). Understanding attitudes and predicting social behavior. Englewood Cliffs, NJ: PrenticeHall.

3) Arnould, E. J., Price, L. L., Zinkhan, G. M. (2004). Consumers, $2^{\text {nd }}$ edition. McGraw-Hill: New York.

4) Bui, T. T. (2014). Evaluation the Chinese factor to the Vietnam's economics and policy recommendations. Autumn Economic Forum. [Vietnamese]

5) Gurhan-Canli, Z., \& Maheswaran, D. (2000). Determinants of Country-of-Origin Evaluations. Journal of Consumer Research, 27(1), 96-108

6) Engel, J. F., Blackwell, R. D., \& Kollat, D. T. (1978). Consumer Behavior. Dryden Press, Hinsdale, IL.

7) Fishbein, M., \& Ajzen, I. (1975). Belief, attitude, intention and behavior. An introductiion to theory and research. Reading, Mass: Addison-Wesley

8) Hair, J.F., Joseph, F.Jr., Anderson, Rolph E., Tatham, Ronald L. and Black, Wiliam C. (1998). Multivariate data analysis, 5th edition, Prentice Hall, Upper Saddle River, NJ.

9) Hair, J.F., Anderson, R.E., Tatham, R.L., \& Black, W.C. (2010). Multivariate Data Analysis. Prentice-Hall International.

10) Hoang, T., \& Chu, N.M.N. (2008), Analysis of research data with SPSS, Hong Duc Publishing House.

11) Howard, J. A. (1963). Marketing Management Analysis and Planning, rev.ed. Richard D.Irwin, Inc., Homewood, IL, ch. 34.

12) Huong, L. T. (2014). A study on factors influencing urban residents' intention to buy safe food - for example in Hanoi city. PhD thesis, National Economics University. [Vietnamese]

13) Jin. B., \& Kang, J. H. (2011). Purchase intention of Chinese consumers toward a US apparel brand: A test of a composite behavior intention model. Journal of Consumer Marketing, 28(3):187-199. DOI: 10.1108/07363761111127617.

14) Marshall, A. (1890). Principles of Economics. London: MacMillan \& Co.

15) Mathur, A. (1998). Incorporating choice into an attitudinal framework: Cross-cultural extension and additional findings. Journal of International Consumer Marketing, 10(4), 93-110.

16) Mien, N. T. N. (2017). Factors affecting the willingness to buy Chinese products: empirical research in Vietnam. Journal of science (An Giang University), 17, 58-68. [Vietnamese]

17) Nhung, N. T, T., Hai, L. T., Phuong, N. V.., Cuc, L. T. T. (2016). Factors affecting the trend of Vietnamese consumption of domestic garments: A study in Gia Lam district, Hanoi city. Journal of Asia-Pacific Economy, 484, 59-61. [Vietnamese]

18) Pierre, C., Morwitz, V. G., Reinartz, W. J. (2005). Do Intentions Really Predict Behavior? Self-Generated Validity Effects in Survey Research. Journal of Marketing, 69(2), 1-14.

19) Schlosser, A. E., White, T. B., \& Lloyd, S. M. (2006). Converting web site visitors into buyers: how web site investment increases consumer trusting beliefs and online purchase intentions. Journal of Marketing, 70(2), 33-148.

20) Thang, H. N. (2015). A study on factors influencing online shopping in Vietnam. PhD thesis, National Economics University. [Vietnamese]

21) Thoa, D. T. K. (2012). Some problems of developing domestic market for garment firms in Vietnam. Journal of Economic Management, 47, 52-56. [Vietnamese]

22) Thong, V. H., \& Ha, L. T. H. (2018). A study on factors affecting consumers' intention to buy Chinese garment products in Hanoi. Journal of Economics and Development, 253, 70-79. [Vietnamese]

23) Thong, V. H. (2003). The values of marketing research from a governance perspective to decision-making. Journal of Economics and Development, 73, 27-29

24) Warshaw, P. R. (1980). A new model for predicting behavioral intentions: An alternative to Fishbein. Journal of Marketing Research, 17(2), 153-172. https://doi.org/10.2307/3150927 